\title{
The effects of intravenous protein-calorie supplementation on the tissue composition of postoperative body weight loss
}

\author{
E. A. Elebute \\ M.D., F.R.C.S., F.R.C.S.E. \\ College of Medicine of University of Lagos, P.M. Bag:12003, Lagos, Nigeria
}

\begin{abstract}
Summary
The components of postoperative body weight loss were analysed in eleven adult male patients who had uncomplicated abdominal surgery of moderate severity namely vagotomy and a drainage procedure for chronic duodenal ulceration. Four patients (Group I) had the routine postoperative regimen which consisted of intravenous isotonic dextrose and dextrose-saline solutions. Another group of four patients (Group IIa) had supplementation of this regimen with $50 \%$ dextrose and an amino-acid/sorbitol preparation whilst a group of three (Group IIb) patients had supplementation with only amino-acid/sorbitol preparation.

Group I patients exhibited the expected losses of lean tissue and body fat, but these were partially obscured by retention of extracellular water. Group IIa exhibited excessive loss of extracellular water which was parallel to an increased urine flow and this loss completely overshadowed the reduction in lean tissue and body fat losses produced by the protein and calorie supplementation. Group IIb patients exhibited the smallest amount of weight loss because they had a reduction in lean tissue and body fat losses whilst they still exhibited a mild antidiuretic response. It is suggested that the amino-acid/sorbitol preparation provides the safest form of supplementation, particularly in the face of increased extra-renal losses of water such as may be dictated by a warm tropical environment.
\end{abstract}

\section{Introduction}

Parenteral hyperalimentation is the term coined by Rhoads to describe the intravenous administration of nitrogen, calories and other nutrients in quantities required to produce tissue synthesis during conditions which are usually associated with a catabolic response. Such a catabolic response is known to occur immediately after moderate to severe surgical trauma (Moore, 1959). It has been shown that the administration of high calorie solutions containing aminoacids produces an early reversal of the negative nitrogen balance that follows trauma (Werner et al.,
1949; Beal, Cornell and Gilder, 1954; Peaston, 1969 ; Spivey and Johnston, 1972). During a study of the effect of increased nitrogen and calorie intakes on nitrogen balance after surgery, it was observed that, in spite of its nitrogen-sparing effect, this regimen did not abolish the weight loss which is characteristic of the immediate post-surgical period. It is known that body weight loss following injury is the algebraic sum of changes in weight of lean tissue, body fat and water (Gilder et al., 1961; Kinney et al., 1968). In order to identify the real implications of weight loss in the presence of high levels of calorie and nitrogen intake, the contributions of changes in various tissue components to total weight must be analysed. This report represents the results of such an analysis carried out on patients who had varying amounts of calorie and nitrogen intake.

\section{Method}

The patients in this study were adult male Nigerians undergoing uncomplicated elective vagotomy and a drainage procedure for chronic duodenal ulceration. They were otherwise healthy and had no evidence of renal disease. Two groups of patients were studied. Group I consisted of four patients who were placed on the routine postoperative regimen employed at Lagos University Teaching Hospital, namely nasogastric suction and intravenous administration of isotonic dextrose or dextrose-saline solution for the first 3-5 postoperative days with gradual resumption of oral feeding as dictated by the absence of abdominal distention and the return of bowel sounds. Group II consisted of seven patients who had supplementation of the routine regimen with high intakes of nitrogen and calories. In four of these patients (Group IIa) the supplementation was given in the form of intravenous infusion of $50 \%$ dextrose and Trophysan Conc. 10, ${ }^{*}$ a synthetic amino-acid mixture which contains in each litre $80 \mathrm{~g}$ of amino-acids

* Manufactured by Servier Laboratories Limited, Harrow Middlesex. 
and $98 \mathrm{~g}$ of sorbitol together with small quantities of minerals and vitamins. The remaining three patients (Group IIb) had only supplementation with Trophysan Conc. 10.

Each patient was admitted into a side-room equipped for metabolic balance studies and in which there was an autographic thermometer* for continuous recording of the room temperature. Each 24-hr period of the metabolic study started at 8 a.m. (local time); and just before 8 a.m. the patient voided the urine in his bladder and was weighed in the nude on a weighing scale which had a sensitivity of $50 \mathrm{~g} . \dagger$ In the later studies the patient's weight was monitored with an in-bed weighing scale with a sensitivity of $25 \mathrm{~g} \ddagger$. The patient's body temperature was measured 4-hourly with an ordinary clinical thermometer placed in the sublingual position. Only patients in which the oral temperature did not rise above $38^{\circ} \mathrm{C}$ during any part of the studies have been included in this report.

During the period of intravenous feeding the intakes of protein, carbohydrate and calories were calculated from the amount of intravenous fluids given and the concentrations of nutrients in each type of fluid employed. The amounts of nitrogen and calorie intake during oral feeding were established directly rather than from tables, since complete tables of the constituents of Nigerian foodstuffs are not available. The amounts of various foodstuffs constituting a meal were weighed separately and the amounts discarded by the patient were also weighed. The foodstuffs were then mixed in the proportion in which they had been eaten by the patient and homogenized in a Waring blender. A sample of the homogenate was dried to constant weight in a desiccator. The nitrogen content of the dried sample was estimated by the micro-Kjeldahl method, and its fat content by extraction with ether, ethanol and acetone. The residue obtained after the fat extraction was digested with concentrated sulphuric acid to determine its crude fibre content and the carbohydrate content of the food sample was estimated by difference. Calorie intake was then calculated by multiplying the protein, carbohydrate, and fat contents by the factors $4 \cdot 1,4 \cdot 1$ and $9 \cdot 3$ respectively. In later studies the caloric value of the dried homogenate was determined directly with aid of a Ballistic Bomb Calorimeter.ई

Urinary nitrogen for each $24-\mathrm{hr}$ period as well as the nitrogen content of any faeces passed during the period was measured by the micro-Kjeldahl tech-

\footnotetext{
* Bimetallic Thermograph Mk 3, Short \& Mason, London. $\dagger$ Avery Scale.

$\ddagger$ Potter Bed Balance, James Addison Porter, West Hartford, Connecticut.

§ Manufactured by Gallenkamp, London.
}

nique. In calculating daily nitrogen balance, no correction was made for nitrogen loss in sweat since it has been shown that in permanent inhabitants of the tropics, the nitrogen concentration of sweat is low and the total loss of nitrogen through this route is negligible (Ashworth and Harrower, 1967).

Changes in the lean tissue content of the body were calculated from the nitrogen balance. The net dry protein loss or gain was obtained by multiplying nitrogen balance by the factor of 6.25 and lean tissue was presumed to contain $79 \%$ of water. The change in body lean tissue was, therefore, obtained from nitrogen balance by multiplying the latter by a factor of 30 .

Changes in body fat were estimated by a modification of Newburgh's formula (Newburgh et al., 1937). Newburgh's formula is based on the concept that $24 \%$ of the body's heat loss takes place through evaporation of water from the body. It has been shown that the proportion of body heat eliminated by vaporization of water varies with the ambient temperature (Dubois, Ebaugh and Hardy, 1952). Therefore, in using the principle of Newburgh's formula to calculate the amount of fat burnt in the body the environmental temperature should be monitored. It has been shown that the air temperature which is most related to heat loss by evaporation in hospitalized patients confined to bed is the temperature of air under the bed clothes (Gilder et al., 1961; Elebute, 1973). In order to obtain an estimate of this temperature, a preliminary study was carried out in surgical patients hospitalized under the same conditions as the patients included in this study.

Most patients on our hospital wards in the warm environment of Lagos cover themselves with a cotton bedsheet or remain in their pyjamas with no extra cover. In the preliminary study, temperature of air under the patient's pyjama shirt was taken, irrespective of whether he had extra cover or not; the temperature being measured with the aid of an electrical thermometer* using a probe which was supported under the pyjama without its touching either the cloth or the patient's body. Ambient temperature in the ward was recorded simultaneously. The mean temperature under the pyjamas in forty-one patients was $30.54^{\circ} \mathrm{C}$, with a range of $27 \cdot 4-34 \cdot 2^{\circ} \mathrm{C}$. The mean ambient temperature was $27 \cdot 16^{\circ} \mathrm{C}$, with a range of $23 \cdot 3-30 \cdot 2^{\circ} \mathrm{C}$. Figure 1 shows the regression of temperature under clothing on ambient temperature. Since the correlation of the two temperatures was statistically significant, this regression line was used to estimate the temperature under clothing from the ambient temperature during the studies reported in this paper.

* Type TR8, manufactured by Ellab, Copenhagen, Denmark. 
Newburgh's formula for calculating the fat burnt in the body is based on the equation of Isenschmid (1918) for insensible weight loss (IL):

$$
\mathrm{IL}=\mathrm{IW}+\mathrm{CO}_{2}-\mathrm{O}_{2}
$$

where IW is the insensible water loss, $\mathrm{CO}_{2}$, the amount of carbon dioxide exhaled and $\mathrm{O}_{2}$, the amount of oxygen consumed. Insensible weight loss (IL) is the difference between the total weight of ingesta and the total weight of excreta, a correction being made for the change in body weight during the period of study. Since IW is a proportion ( $x \%$ ) of total heat loss (cal) which is eliminated by vaporization of water,

$$
\text { IW } \times 0.58 \times \frac{100}{x}=\text { cal }
$$

0.58 being the latent heat of vaporization of water. Energy output can be calculated from the metabolic mixture thus:

$$
\mathrm{cal}=4 \cdot 1 \mathrm{C}+26 \cdot 5 \mathrm{~N}+9 \cdot 3 \mathrm{~F},
$$

where $\mathrm{C}$ is the carbohydrate intake, $\mathrm{N}$, the urinary nitrogen and F, the fat burnt. From (2) and (3) above,

$$
\begin{gathered}
I W=\frac{x(4 \cdot 1 C+26.5 N+9 \cdot 3 F)}{58} \\
=0.0707 x C+0.457 x N+0.1603 x F
\end{gathered}
$$

The difference between the carbon dioxide produced and the oxygen consumed is given by the following equation (Lavietes, 1935):

$$
\mathrm{CO}_{2}-\mathrm{O}_{2}=0.41 \mathrm{C}+0.84 \mathrm{~N}-0.08 \mathrm{~F}
$$

From (1), (4) and (5) above,

$$
\begin{aligned}
& \mathrm{IL}=0 \cdot 0707 \mathrm{xC}+0 \cdot 457 \mathrm{xN}+0 \cdot 1603 \mathrm{xF} \\
& +0.41 \mathrm{C}+0.84 \mathrm{~N}-0.08 \mathrm{~F} \text {, and } \\
& F=\frac{I L-(0.0707 x C+0.41 C+0.457 x N+0.84 N)}{0 \cdot 1603 x-0.08}
\end{aligned}
$$

In order to estimate the value of $x$ in equation (6), the mean ambient temperature was calculated from the autographic record taken for each 24-hr of the study. The mean temperature under clothing was then derived from the regression equation illustrated in Fig. 1, and the proportion of heat lost by vaporization of water at this temperature was read from a graph prepared from the data of Dubois et al. (1952) (Fig. 2). Having calculated the amount of fat burnt in the metabolic mixture, the net loss or gain of anhydrous fat was then found by the difference between the fat burnt and the fat intake. The change in body fat was calculated by multiplying this difference by the factor of 1.11 since adipose tissue contains $10 \%$ of water. The difference between the total body weight change and the sum of changes in lean tissue and body fat is the change in what Kinney and his colleagues (1968) termed 'excess water'. The total

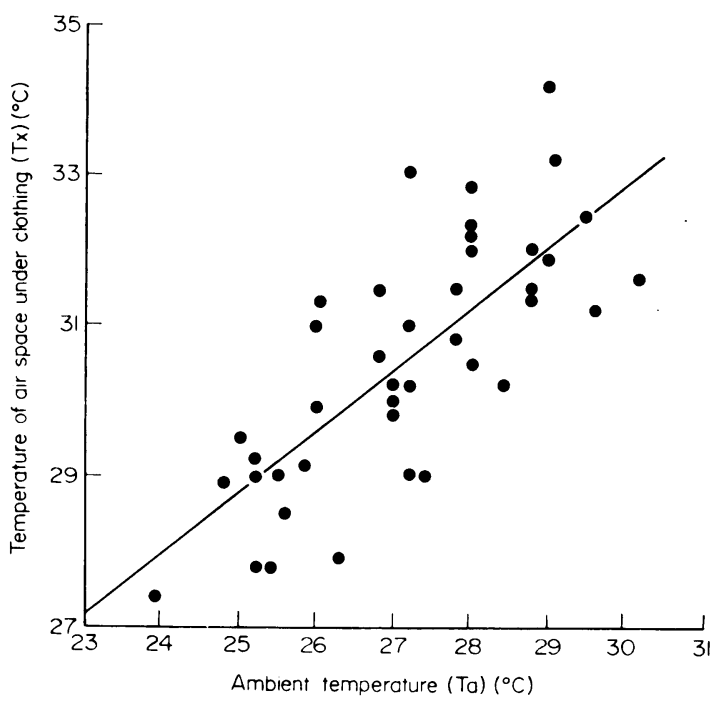

FIG. 1. Regression analysis of temperature of air space under patients' clothing on ambient temperature. $\mathrm{y}=0.818 \mathrm{x}+8.32 ; \mathrm{r}=0.763 ; P<0.001$.

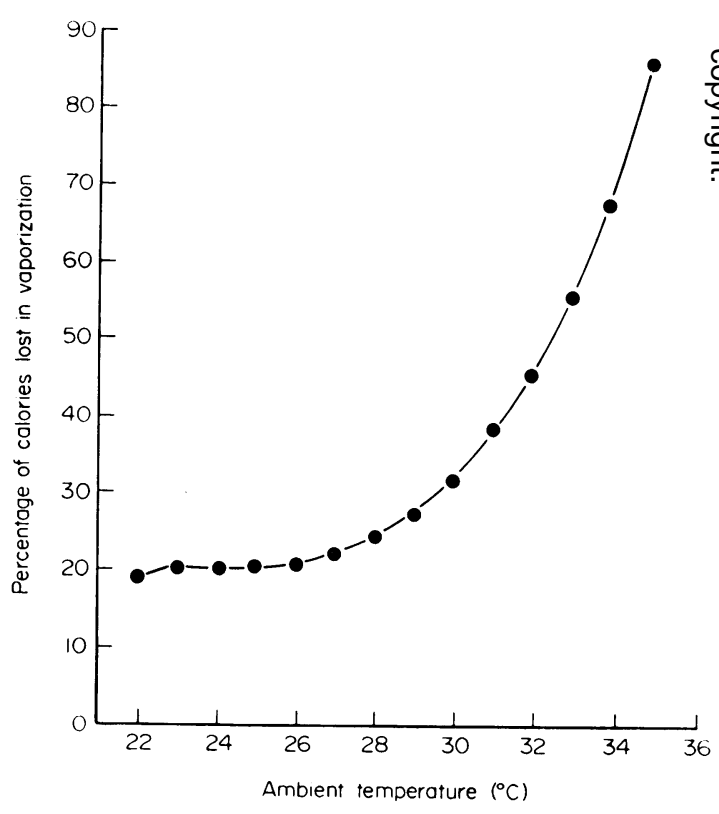

FIG. 2. Relationship of heat loss by vaporization of water to ambient temperature. Graph drawn from the data of Dubois, Ebaugh and Hardy (1952).

change in body water is the sum of this "excess water' and the water content of the losses or gains of lean tissue and body fat, lean tissue being presumed to contain $79 \%$ water and body fat $10 \%$.

The osmotic load delivered into the patient's vascular system through intravenous feeding in each 
24-hr period was calculated from the amount of each type of intravenous fluid given and the osmolality of the fluid. The osmolality of a sample of each intravenous fluid employed was determined with Fiske Osmometer.

The entire study on each patient was divided into two 4-day periods. Period I was the day of operation and the first 3 days that followed it. Period II was the 4-day period following immediately after Period I. The changes in body weight change and the tissue components of body weight observed in the groups of patients were compared statistically, using Wilcoxon's two-sample rank test. The statistical relationships of variables measured or calculated during this study were evaluated by calculating Spearman's rank correlation coefficient for pairs of variables.

\section{Results}

Table 1 presents the calorie intake, water intake, intravenous osmolar load and urine volume for all patients studied during Period I. Group I patients had an average of $491 \mathrm{kcal} /$ day, all of which were supplied in the form of carbohydrate, whilst Groups IIa and IIb had $2186 \mathrm{kcal}$ and $897 \mathrm{kcal} /$ day respectively in the form of both protein and carbohydrates. Water intake was similar for all groups but osmotic load and urine volume were much higher in Group IIa than in either Group I or Group IIb.

Table 2 presents the changes in body weight and its tissue components for all patients during Period I. The average weight loss was $7.86 \mathrm{~g} / \mathrm{kg}$ body weight per day, $12.75 \mathrm{~g} / \mathrm{kg}$ body weight per day and 2.69 $\mathrm{g} / \mathrm{kg}$ body weight per day for Group I, Group IIa

TABle 1. Calorie intake, water intake, intravenous osmolar load and urine volume during Period I

\begin{tabular}{lcccccccc}
\hline Group & Patient & $\begin{array}{c}\text { Total } \\
\text { Calorie } \\
\text { intake, } \\
\text { kcal/day }\end{array}$ & $\begin{array}{c}\text { Calories } \\
\text { from } \\
\text { protein, } \\
\text { kcal/day }\end{array}$ & $\begin{array}{c}\text { Calories } \\
\text { from } \\
\text { fat, } \\
\text { kcal/day }\end{array}$ & $\begin{array}{c}\text { Calories } \\
\text { from } \\
\text { carbohydrate, } \\
\text { kcal/day }\end{array}$ & $\begin{array}{c}\text { Water } \\
\text { intake, } \\
\text { ml/day }\end{array}$ & $\begin{array}{c}\text { Intravenous } \\
\text { osmotic load, } \\
\text { mOsm/day }\end{array}$ & $\begin{array}{c}\text { Urine } \\
\text { volume, } \\
\text { ml/day }\end{array}$ \\
\hline I & 1 & 504 & $0 \cdot 0$ & $0 \cdot 0$ & 504 & 2313 & 784 & 1238 \\
& 2 & 425 & $0 \cdot 0$ & $0 \cdot 0$ & 425 & 2144 & 643 & 1293 \\
& 3 & 500 & $0 \cdot 0$ & $0 \cdot 0$ & 500 & 2621 & 786 & 773 \\
Average for & 4 & 534 & $0 \cdot 0$ & $0 \cdot 0$ & 534 & 2240 & 672 & 646 \\
Group I & & 491 & $0 \cdot 0$ & $0 \cdot 0$ & 491 & 2405 & 721 & 988 \\
IIa & 5 & 2016 & 328 & $0 \cdot 0$ & 1688 & 2572 & 3980 & 2713 \\
& 6 & 1969 & 164 & $0 \cdot 0$ & 1805 & 2667 & 3028 & 2240 \\
& 7 & 2304 & 246 & $0 \cdot 0$ & 2058 & 3205 & 3659 & 2475 \\
Average for & 8 & 2453 & 230 & $0 \cdot 0$ & 2223 & 2762 & 3907 & 1790 \\
Group IIa & & 2186 & 242 & $0 \cdot 0$ & 1943 & 2802 & 3644 & 2305 \\
IIb & 9 & 815 & 188 & $0 \cdot 0$ & 627 & 3067 & 1464 & 1094 \\
& 10 & 1040 & 342 & $0 \cdot 0$ & 698 & 2843 & 1965 & 1301 \\
Average for & 11 & 837 & 298 & $0 \cdot 0$ & 539 & 2043 & 1659 & 1241 \\
Group IIb & & 897 & 276 & $0 \cdot 0$ & 621 & 2651 & 1696 & 1212 \\
\hline
\end{tabular}

TABLE 2. Changes in body weight and its tissue components during Period I, expressed in $\mathrm{g} / \mathrm{kg}$ body weight per day

\begin{tabular}{|c|c|c|c|c|c|c|}
\hline Group & Patient & $\Delta$ Body weight & $\Delta$ Lean tissue & $\Delta$ Body fat & $\Delta$ 'Excess water' & $\Delta$ Body water \\
\hline I & $\begin{array}{l}1 \\
2 \\
3 \\
4\end{array}$ & $\begin{array}{r}-4.42 \\
+0.61 \\
-15.59 \\
-12.05\end{array}$ & $\begin{array}{l}-4 \cdot 92 \\
-8 \cdot 06 \\
-5 \cdot 29 \\
-3 \cdot 79\end{array}$ & $\begin{array}{l}-3 \cdot 40 \\
-2 \cdot 43 \\
-7 \cdot 54 \\
-6 \cdot 26\end{array}$ & $\begin{array}{r}+3 \cdot 90 \\
+11 \cdot 10 \\
-2 \cdot 76 \\
-2 \cdot 00\end{array}$ & $\begin{array}{l}-0.33 \\
+4.49 \\
-7.69 \\
-5.62\end{array}$ \\
\hline \multicolumn{2}{|c|}{$\begin{array}{l}\text { Average for } \\
\text { Group I }\end{array}$} & $-7 \cdot 86$ & $-5 \cdot 51$ & $-4 \cdot 91$ & $+2 \cdot 56$ & $-2 \cdot 29$ \\
\hline IIa & $\begin{array}{l}5 \\
6 \\
7 \\
8\end{array}$ & $\begin{array}{r}-10 \cdot 96 \\
-10 \cdot 86 \\
-25 \cdot 60 \\
-3 \cdot 58\end{array}$ & $\begin{array}{l}-4 \cdot 80 \\
-3 \cdot 72 \\
-2 \cdot 79 \\
-4 \cdot 49\end{array}$ & $\begin{array}{r}+4.42 \\
+2.85 \\
+1.83 \\
+5.71\end{array}$ & $\begin{array}{r}-10 \cdot 58 \\
-9.99 \\
-24 \cdot 64 \\
-4 \cdot 80\end{array}$ & $\begin{array}{r}-13 \cdot 93 \\
-12 \cdot 64 \\
-26 \cdot 66 \\
-7 \cdot 76\end{array}$ \\
\hline \multicolumn{2}{|c|}{ Group IIa } & \multicolumn{4}{|c|}{ Average for } & $-15 \cdot 25$ \\
\hline IIb & $\begin{array}{r}9 \\
10 \\
11\end{array}$ & $\begin{array}{r}+0 \cdot 22 \\
-3 \cdot 32 \\
-4 \cdot 98\end{array}$ & $\begin{array}{l}-3 \cdot 68 \\
-1 \cdot 03 \\
-3 \cdot 71\end{array}$ & $\begin{array}{r}-2 \cdot 51 \\
-1 \cdot 19 \\
+0 \cdot 29\end{array}$ & $\begin{array}{r}-6 \cdot 41 \\
-1 \cdot 10 \\
-1 \cdot 56\end{array}$ & $\begin{array}{l}+3 \cdot 25 \\
-2 \cdot 03 \\
-4 \cdot 46\end{array}$ \\
\hline \multicolumn{2}{|c|}{ Average for } & $-2 \cdot 60$ & $-2 \cdot 80$ & $-1 \cdot 14$ & $+1 \cdot 25$ & $-1 \cdot 08$ \\
\hline
\end{tabular}


TABLE 3. Levels of significance $(P)$ obtained from statistical comparison of body weight changes shown by various groups of patients*

\begin{tabular}{lcc}
\hline & $\begin{array}{c}\text { Comparison of } \\
\text { Groups I and II }\end{array}$ & $\begin{array}{c}\text { Comparison of } \\
\text { Groups I and IIa }\end{array}$ \\
\hline$\Delta$ Body weight & $>0.05$ & $>0.05$ \\
$\Delta$ Lean tissue & $<0.05$ & $>0.05$ \\
$\Delta$ Body fat & $<0.05$ & $<0.05$ \\
$\Delta$ 'Excess water' & $>0.05$ & $<0.05$ \\
$\Delta$ Body water & $>0.05$ & $<0.05$ \\
\hline
\end{tabular}

* Statistical comparison was by Wilcoxon's two-sample rank test.

and Group IIb respectively. Group I patients lost the greatest amount of lean tissue. Group IIa gained in respect of body fat whilst the others lost, Group IIb's loss being much less than that of Group I. Both Group I and Group IIb tended to retain small amounts of 'excess water' whilst Group IIa exhibited a major loss of 'excess water', namely 12.50 $\mathrm{g} / \mathrm{kg}$ body weight per day. Statistical comparison of Groups I and II by Wilcoxon's two-sample rank test showed that there were significant differences between the two groups in the changes of lean tissue and body fat (Table 3). Similar comparison of Group I with Group IIa showed significant differences in the changes in body fat, 'excess water', and body water. The calculation of Spearman's rank correlation coefficients for pairs of variables showed that some of the tissue components of weight loss during Period I were significantly correlated to specific variables on the intake side. Changes in lean tissue correlated significantly with protein intake $\left(\mathrm{r}_{\mathrm{s}}=\right.$ $0.66 ; P<0.05)$; and changes in body fat correlated with total calorie intake $\left(\mathrm{r}_{\mathrm{s}}=0.864 ; P<0.01\right)$. Changes in the 'excess water' component correlated significantly with total calorie intake $\left(r_{\mathrm{s}}=-0.727\right.$ $P<0.05)$ and intravenous osmotic load $\left(\mathrm{r}_{\mathrm{s}}=\right.$ $-0.754 ; P<0.01)$. Urine output also correlated significantly with intravenous osmotic load $\left(\mathrm{r}_{\mathrm{s}}=\right.$ $0.81 ; P<0.001)$ but failed to correlate significantly with water intake $\left(r_{s}=0.28 ;\right.$ n.s. $)$.

Table 4 presents the calorie intake, water intake and urine output of the patients during Period II; and Table 5 presents the changes in body weight and its tissue components during this period. During this period there was a general tendency to reduction in weight loss from the level observed in Period I or, in some patients, a reversal to actual weight gain. This trend was mostly due to changes in 'excess water'. The tendency to an increase in this component of body weight observed in Group I patients during Period I became accentuated as shown by an average gain of $10.52 \mathrm{~g} / \mathrm{kg}$ per day as compared with $2.56 \mathrm{~g} / \mathrm{kg}$ per day during Period I. The marked losses of this component suffered by Group IIa patients during Period I became reversed so that during Period II there was an average gain of $4.62 \mathrm{~g} / \mathrm{kg}$ per day in contrast to an average loss of $12.50 \mathrm{~g} / \mathrm{kg}$ per day during Period I. Running parallel to the changes in the 'excess water' component during the two periods was the urinary output. Group IIa exhibitec a marked diuresis during Period $I$ in contrast to a antidiuretic response exhibited by the other patientso particularly those in Group I (Fig. 3).

\section{Discussion}

Weight loss after surgical trauma is a reflection of the metabolic effects which result in a loss of lean tissue and oxidation of fat. Benedict (1915) showed that from weight changes and nitrogen balance it was possible to deduce the relative combustion of fat and

TABLE 4. Calorie intake, water intake and urine volume Period II

\begin{tabular}{|c|c|c|c|c|c|c|c|}
\hline Group & Patient & $\begin{array}{c}\text { Total } \\
\text { calorie } \\
\text { intake, } \\
\text { kcal/day }\end{array}$ & $\begin{array}{l}\text { Calories } \\
\text { from } \\
\text { protein, } \\
\text { kcal/day }\end{array}$ & $\begin{array}{c}\text { Calories } \\
\text { from } \\
\text { fat, } \\
\mathrm{kcal} / \text { day }\end{array}$ & $\begin{array}{c}\text { Calories } \\
\text { from } \\
\text { carbohydrate, } \\
\text { kcal/day }\end{array}$ & $\begin{array}{l}\text { Water } \\
\text { intake, } \\
\text { ml/day }\end{array}$ & $\begin{array}{c}\text { Urine } \\
\text { volume, } \\
\text { ml/day }\end{array}$ \\
\hline \multirow[t]{4}{*}{ I } & 1 & 386 & 80 & $0 \cdot 0$ & 306 & 2378 & 2625 \\
\hline & 2 & 367 & 20 & 99 & 248 & 1621 & 1413 \\
\hline & 3 & 465 & 22 & 0.0 & 443 & 2498 & 1605 \\
\hline & 4 & 231 & 22 & $0 \cdot 0$ & 209 & 2142 & 1053 \\
\hline \multicolumn{8}{|c|}{ Average for } \\
\hline \multicolumn{2}{|c|}{ Group I } & 362 & 36 & 25 & 301 & 2160 & 1674 \\
\hline \multirow[t]{4}{*}{$11 \mathrm{a}$} & 5 & 1760 & 251 & 655 & 854 & 3045 & 1090 \\
\hline & 6 & 1446 & 203 & 298 & 945 & 2751 & 1888 \\
\hline & 7 & 1784 & 152 & 21 & 1611 & 3946 & 2061 \\
\hline & 8 & 1092 & 143 & 0.0 & 949 & 3246 & 1138 \\
\hline \multicolumn{8}{|c|}{ Average for } \\
\hline \multicolumn{2}{|c|}{ Group IIa } & 1521 & 187 & 244 & 1090 & 3247 & 1544 \\
\hline $11 b^{*}$ & 9 & 815 & 168 & 0.0 & 647 & 3067 & 2054 \\
\hline & 10 & 711 & 135 & 35 & 541 & 2870 & 1458 \\
\hline
\end{tabular}

* Adequate data were not obtained from patient No. 11 to permit analysis of tissue components of body weight loss during this period; hence averages were not calculated for Group IIb. 
TABLE 5. Changes in body weight and its tissue components during Period II, expressed in $\mathrm{g} / \mathrm{kg}$ body weight per day

\begin{tabular}{|c|c|c|c|c|c|c|}
\hline Group & Patient & $\Delta$ Body weight & $\Delta$ Lean tissue & $\Delta$ Body fat & $\Delta$ 'Excess water' & $\Delta$ Body water \\
\hline I & $\begin{array}{l}1 \\
2 \\
3 \\
4\end{array}$ & $\begin{array}{r}+10.85 \\
-6.25 \\
+15.59 \\
+11.45\end{array}$ & $\begin{array}{l}-3 \cdot 67 \\
-4 \cdot 87 \\
-2 \cdot 58 \\
-4 \cdot 02\end{array}$ & $\begin{array}{l}+5 \cdot 72 \\
-1 \cdot 12 \\
+1 \cdot 51 \\
-1 \cdot 39\end{array}$ & $\begin{array}{r}+8.80 \\
-0.26 \\
+16.66 \\
+16.86\end{array}$ & $\begin{array}{r}+11.74 \\
-5.59 \\
+16.07 \\
+11.97\end{array}$ \\
\hline $\begin{array}{l}\text { Average for } \\
\text { Group I }\end{array}$ & & $+7 \cdot 91$ & $-3 \cdot 78$ & $+1 \cdot 18$ & $+10 \cdot 52$ & $+8 \cdot 55$ \\
\hline Group IIa & $\begin{array}{l}5 \\
6 \\
7 \\
8\end{array}$ & $\begin{array}{r}0.00 \\
-0.24 \\
+6 \cdot 07 \\
-1 \cdot 25\end{array}$ & $\begin{array}{l}-1 \cdot 38 \\
-1 \cdot 07 \\
-4 \cdot 25 \\
-3 \cdot 94\end{array}$ & $\begin{array}{r}-1 \cdot 78 \\
+1.34 \\
+1.93 \\
-4 \cdot 73\end{array}$ & $\begin{array}{l}+3 \cdot 16 \\
-0 \cdot 51 \\
+8 \cdot 39 \\
+7 \cdot 42\end{array}$ & $\begin{array}{l}+0.10 \\
+6.83 \\
+6.83 \\
-0.94\end{array}$ \\
\hline $\begin{array}{c}\text { Average for } \\
\text { Group IIa }\end{array}$ & & $+1 \cdot 14$ & $-2 \cdot 66$ & $-0 \cdot 81$ & $+4 \cdot 62$ & $+1 \cdot 50$ \\
\hline Group IIb* & $\begin{array}{r}9 \\
10\end{array}$ & $\begin{array}{l}-9 \cdot 27 \\
+0.74\end{array}$ & $\begin{array}{l}-7 \cdot 69 \\
-2 \cdot 03\end{array}$ & $\begin{array}{l}-4 \cdot 10 \\
-1 \cdot 84\end{array}$ & $\begin{array}{l}+2 \cdot 52 \\
+4 \cdot 61\end{array}$ & $\begin{array}{l}-8 \cdot 37 \\
+0.93\end{array}$ \\
\hline
\end{tabular}

* Adequate data were not obtained from patient No. 11 to permit analysis of tissue components of body weight loss during this period; hence averages were not calculated for Group IIb.

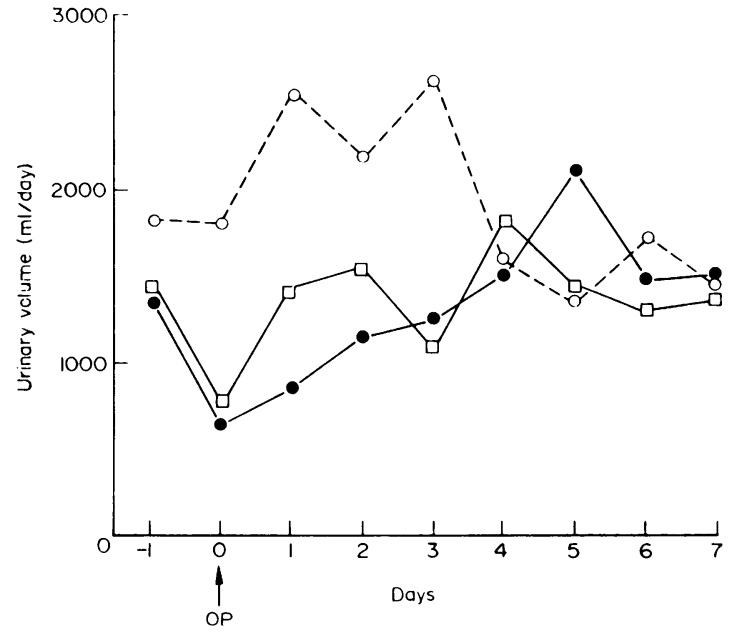

FIG. 3. Daily urine output in the immediate postoperative period. Note the diuresis exhibited by Group IIa patients in contrast with the oliguric effect shown by other patients. $\odot$, Group I patients; $\odot$, Group IIa patients; $\square$ Group IIb patients.

lean tissue in starvation. Similarly, determination of tissue components of body weight loss after surgery reveal the relative metabolic effects of surgery on various tissues in the body and the extent to which these effects may be altered or obscured by treatment.

The availability of sensitive bed scales has facilitated the monitoring of body weight in surgical patients during the postoperative period. However, methods available for estimating the contributions of various tissues to weight loss are fraught with many sources of error.

In this study, changes in lean tissue have been determined by multiplying the nitrogen balance by a factor of 30 based on the conversion of nitrogen to protein by the factor of 6.25 and the approximation that lean tissue contains $79 \%$ water. The validity of determining lean tissue changes from nitrogen balance has been widely acknowledged (Gilder et al., 1961); but the conversion factor employed has been variable. It is well known that the factor for converting nitrogen content to protein content should vary from one protein to another. For example, it is about 5.7 for some vegetable proteins, up to 6.4 for some animal proteins, and 6.1 for the synthetic amino-acid mixture used in the present study. However, the factor of 6.25 was selected as an approximation for proteins incorporated into or lost from the body (Davidson and Passmore, 1966; Kinney et al., 1968), and used for calculating nitrogen balance. Values reported for water of hydration of lean tissue have varied from 71 to $83 \%$ (Berlin, Watkin and Gevirtz, 1962; Brozek, 1961; Grande, 1968; Moore and Ball, 1952; Wedgwood, 1963). The choice of $79 \%$ used in this study has the advantage of making the conversion factor the round figure of 30 .

There are various indirect methods for determining changes in body fat. Methods depending on measurement of body density (Burskirk, 1961; Siri, 1961) are not technically applicable to the study of acutely ill post-surgical patients. Derivation of body fat changes from total body water, using the formula of Pace and Rathburn (1945), is only valid under conditions of normal hydration and is not sensitive enough to investigate short-term weight loss. Indirect calorimetry has been shown to be a relatively accurate method for measuring body fat changes (Gilder et al., 1967; Kinney et al., 1968); but, because of the use of intermittent expired-air analyses to estimate metabolism during the entire period of study, even this method has unavoidable sources of error. In this study, body fat changes were calculated from a modification of Newburgh's formula (Newburgh et al., 1937). It has been shown that this method compares 
favourably with the expired-air analysis method (Gilder et al., 1967). Newburgh's formula depends on the assumption that insensible water loss represents a constant proportion of heat loss by the body. The observation of Dubois et al. (1952) that the proportion of heat loss eliminated by vaporization of water varies with ambient temperature has been employed to modify Newburgh's formula. Also, the behavioural element in temperature regulation in adult humans implies that the environmental temperature which is most closely related to heat loss is the temperature of the air space under their clothing. A preliminary study showed that within the temperature range prevailing on our wards in Lagos this temperature rose with ambient temperature and, therefore, could be estimated from it. It must be stressed also that Newburgh's formula presumes an intact thermoregulatory mechanism. For this reason the precaution was taken not to include in this study any patient whose oral temperature rose above $38^{\circ} \mathrm{C}$. This level was selected because the studies of Gump et al. (1968) have shown that it would cause evaporative water loss to increase by about $15 \%$ above the rate recorded at normal body temperature. This degree of increase in evaporative water loss will produce only small errors in the determination of changes in body fat. For example, other variables remaining unchanged, in our Group I patients, it will produce an average of $24 \%$ increase in the body fat loss, i.e. an error of about $48 \mathrm{~g}$; and, in our Group IIa patients, there will be an average of $14 \%$ fall in the amount of fat gain observed, i.e. an error of about $25 \mathrm{~g}$. These errors are small and are within the range of the sensitivity of our weighing scales.

The extent of weight loss observed in our patients is similar to the amount previously reported after abdominal surgery of moderate severity. Paquin and Lange (1956) reported a loss of $6 \cdot 2 \mathrm{~g} / \mathrm{kg}$ body weight per day in the first 5 days after operation, while the value reported by Gilder et al. (1961) for patients who had the routine regimen of intravenous isotonic dextrose and dextrose-saline solutions is $6.61 \mathrm{~g}$ when reduced to weight per $\mathrm{kg}$ body weight per day. Both of these values are similar to our result of $7.86 \mathrm{~g} / \mathrm{kg}$ body weight per day for our Group I patients during Period I.

The analysis of tissue components of body weight loss during the first 4 postoperative days in the patients who had only intravenous isotonic dextrose and dextrose-saline yielded results which were in consonance with the well-known metabolic response to injury, namely increased catabolism of body protein and oxidation of body fat. These processes implied a loss of body water but the extent of this loss was partially obscured by the retention of extracellular fluid due to the well-known antidiuretic response to injury. The tendency to retain extracellular water continued into the second period of the study. Some of the patients studied by Gilder et al. (1961) exhibited a similar retention of extracellular fluid during the second 5-day period after surgery.

The patients who had supplementation with intravenous amino-acids, sorbitol and $50 \%$ dextrose exhibited a marked loss of extracellular water and this was due to the osmotic diuresis produced by the huge osmotic load delivered into their blood stream. These patients exhibited the most severe weight loss because the loss of water completely overshadowed the reduction of lean tissue loss and the gain in body fat produced by their increased protein and calorie intakes. It is possible that if a lower concentration of dextrose, such as a $20 \%$ solution, is used to supply extra calories, less osmotic diuresis may result.

In contrast to the patients who received both $50 \%$ dextrose and the amino-acid/sorbitol preparation, those who had supplementation with only aminoacid and sorbitol exhibited the smallest amount of weight loss because the reduction in lean tissue and body fat losses produced by the supplementation was not counteracted by increased loss of extracellular water. Therefore, it appears that although the aminoacid/sorbitol preparation does not completely nullify the combustion of body fat, it gives the safest form of supplementation. This is because it does not increase renal excretion of water to levels which may be ine appropriate, particularly in the face of increasect extra-renal losses of water such as may be dictated by a tropical environment.

\section{Acknowledgments}

I am grateful to Mrs O. A. Solanke for her technical assistance and to Sister R. Iwang and A. O. Olufuwa who supervised the metabolic studies. The weather data were recorded as part of a Joint Bio-meteorological Project that is being conducted by the Meteorological Services of Nigeria and the Department of Surgery, Lagos University Teaching Hospital. I also wish to thank Dr O. A. Elebute who estimated the osmolalities of samples of intravenous fluids employed in the study.

\section{References}

Ashworth, A. \& Harrower, A.D.B. (1967) Protein requirements in tropical countries: nitrogen losses in sweat and their relationship to nitrogen balance. British Journal of Nutrition, 21, 833.

Beal, J.M., Cornell, G.N. \& Gilder, H. (1954) Factors influencing nitrogen metabolism in surgical patients. Surgery, 36, 468.

Benedict, F.G. (1915) A Study of Prolonged Fasting. Washington: Carnegie Institute of Washington.

Berlin, N.I., Watkin, D.M. \& GevirTz, N.R. (1962) Measurement of changes in gross body composition during controlled weight reduction in obesity by metabolic balance and body density-body water techniques. Metabolism, 11, 302.

BrozeK, J. (1961) Body Composition. Science, 134, 920.

BURSKIRK, E.F. (1961) In: Techniques for Measuring Body Composition. Washington, D.C., National Academy of Sciences, National Research Council. 
Davidson, SiR Stanley \& Passmore, R. (1966) Human Nutrition and Dietetics. Third Edition. Edinburgh: E. \& S. Livingstone.

Dubois, E.F., Ebaugh, F.G., JR \& Hardy, J.D. (1952) Basal heat production and elimination of thirteen normal women at temperatures from $22^{\circ} \mathrm{C}$ to $35^{\circ} \mathrm{C}$. Journal of Nutrition, 48, 257.

ElEbUTE, E.A. (1973) Relationship of skin temperatures of clothed adult males to ambient temperatures in a warm environment. African Journal of Medical Sciences (in press).

Gilder, H., Cornell, G.N., Grafe, W.R., Macfarlane, J.R., Asaph, J.W., Stubenbord, W.T., Watkins, G.M., RESS, J.R. \& ThORBJANARSON, B. (1967) Components of weight loss in obese patients subjected to prolonged starvation. Journal of Applied Physiology, 23, 304.

Gilder, H., Moody, F.G., Cornell, G.N. \& Beal, J.M. (1961) Components of body weight loss in surgical patients. Metabolism, 10, 134.

GrandE, F. (1968) Energy balance and body composition changes. Annals of Internal Medicine, 68, 467.

Gump, F.E., Kinney, J.M., Long, C.L. \& Gelber, R. (1968) Measurement of water balance-a guide to surgical care. Surgery, 64, 154.

ISENSCHMID (1918) Die Bestimmung der Wasserbilanz am Krankenbett. Medizinische Klinik, Berlin, 14, 1128.

KinNey, J.M., LONG, C.L., GuMP, F.E. \& DUKE, J.H., JR (1968) Tissue composition of weight loss in surgical patients. Annals of Surgery, 168, 459.

LAVIETES, P.H. (1935) The metabolic measurement of the water exchange. Journal of Clinical Investigation, 14, 57.
Moore, F.D. (1959) Metabolic care of the Surgical Patient. Philadelphia: W. B. Saunders Co.

Moore, F.D. \& Ball, M.R. (1952) The Metabolic Response to Surgery. Springfield Ill.: Charles C. Thomas.

Newburgh, L.H., Johnston, M.W., Lashmet, F.H. \& SHELDON, J.M. (1937) Further experiences with the measurement of heat production from insensible loss of weight. Journal of Nutrition, 13, 203.

Pace, N. \& Rathburn, E. (1945) Studies on body composition III. The body water and chemically combined nitrogen content in relation to fat content. Journal of Biological Chemistry, 158, 685.

Paquin, A.J. \& Lange, J. (1956) Studies on postoperative body weight loss. Annals of Surgery, 144, 809.

Peaston, M.J.T. (1969) Modification of the early metabolic response to trauma by adaptive calorie-nitrogen feeding. British Journal of Clinical Practice, 23, 11.

SIRI, W.E. (1961) In: Techniques for Measuring Body composition. Washington, D.C.: National Academy of Sciences, National Research Council.

SPIVEY, J. \& JohnSTON, I.D.A. (1972) The effect of environmental temperature and nutritional intake on the metabolic response to abdominal surgery. British Journal of Surgery, $59,93$.

WEDGWOOD, R.J. (1963) Inconstancy of the lean body mass. Annals of the New York Academy of Sciences, 110, 141.

Werner, S.C., Habif, D.V., Randall, H.T. \& LockWoOd, J.S. (1949) Postoperative nitrogen loss. A comparison of the effects of trauma and of calorie adjustment. Annals of Surgery, 130, 688. 